\title{
TOPIC, LOGICAL SUBJECT AND SENTENCE STRUCTURE IN HUNGARIAN
}

\author{
ZSUZSANNA GÉCSEG \\ Department of French Language and Literature \\ University of Szeged \\ Egyetem utca 2 \\ H-6722 Szeged \\ Hungary \\ gecsegz@lit.u-szeged.hu
}

\begin{abstract}
This paper investigates the "discourse-configurationality" hypothesis in Hungarian, based on the current assumption that Hungarian sentence structure is largely determined by information structure. It argues for the necessity of differentiating between the notion of topic, defined on a pragmatic level with respect to possible contexts, and the notion of logical subject, defined on a decontextualized logico-semantic level. On the basis of the distinction between these two levels of sentence analysis, Hungarian should be taken as a logical subject-prominent language rather than a topic-prominent one. As for the so-called contrastive topic in Hungarian, only a subclass of contrastive topic expressions meets the topicality conditions established in this paper on a pragmatic ground, and other types of contrastive topic expressions, namely those that can hardly be differentiated from ordinary topics, display the properties of logical subjects rather than topics.
\end{abstract}

Keywords: topic, logical subject, word order, thetic judgment, categorical judgment

\section{Introduction}

The aim of this paper is to investigate the so-called "discourse-configurationality" of Hungarian, based on the current assumption that Hungarian sentence structure is largely determined by information structure. According to this assumption, Hungarian sentences belong to two basic types: the first has a topic-comment (or logical subject-logical predicate) structure and the second is topicless, consisting of a complex logical predicate (see É. Kiss 1994; 2002 and Szabolcsi 1997). The topic constituents 
occupy the first position(s) in the preverbal field (the Spec of one or several TopPs dominating each other) and the comment is constituted by the VP and various operators (such as distributive quantifiers, focalized expressions and verbal modifiers) preceding the verb. The two types of sentence structure are exemplified by (1) and (2), respectively:

(1) Marit elütötte a vonat.

Mary-acc ran over the train

'Mary has been run over by the train.'

(2) (a) Megérkezett Feri.

arrived Feri

'Feri has arrived.'

(b) Minden gyerek/ (még) Feri is/ sok gyerek olvasta ezt a könyvet. all/every child/ (even) Feri also/ many child read this the book

'Every child/even Feri has read this book./

Many children have read this book'

In (1), the constituent Marit 'Mary-acc' plays the role of the topic; i.e., it refers to the individual about which something is asserted by the predicate elütötte a vonat 'has been run over by the train'. As for (2a), the verb megérkezett 'has arrived' occupies a sentence-initial position and the sentence is not interpreted as an assertion about Feri, but as a complex predicate reporting a certain event. In $(2 \mathrm{~b})$, the preverbal positions are filled by distributive quantifiers that do not serve to denote an individual, but to quantify over individuals, consequently, they take part in the main predication expressed by the whole sentence.

In this paper I will argue for the claim that the terms "topic" and "logical subject" are far from being synonymous, but belong to two distinct levels of information structure: the former is contextually determined and as such is part of the so-called pragmatic articulation, whereas the latter should be taken as a context-free notion, defined on a semantico-logical ground.

After an overview of current assumptions in Hungarian linguistics about the properties of the logical subject in section $\mathbf{1}$, problems connected with these assumptions will be raised in section $\mathbf{2}$. In section $\mathbf{3}$, it will be pointed out that the distinction between thetic judgments and categorical judgments, often related to the distinction between topicless sentences and those with a topic-comment articulation, has been interpreted in rather divergent ways since the works of Marty and Brentano 
and these divergences can be the source of confusion between separate levels of sentence analysis. In section $\mathbf{4}$, I will present my proposal, namely that word order in Hungarian sentences is determined on a semanticological level of information structure rather than a pragmatic one. The proposal will be based on two distinct definitions of the notions of logical subject and topic. As a consequence, a constituent that plays the role of logical subject is not necessarily the topic of the sentence in a particular context. I will also argue for the claim that contrastive topics display some properties that show that these constituents are more related to pragmatic articulation than the ordinary topic is. Finally, in section 5, I will briefly characterize a spoken version of French, called colloquial French, and I will point out that this version of French is essentially a topic-prominent language, as opposed to Hungarian, which should be taken as having a logical subject-logical predicate articulation.

\section{The properties of topic (logical subject) expressions in Hungarian}

In Hungarian, the constituents ${ }^{1}$ that play the role of topic in a particular sentence are usually characterized by means of syntactic, prosodic and semantic criteria.

If the preverbal field of the sentence is filled by some material, its constituents must appear in a strict order. The sentence topic occupies the leftmost position, followed by the logical predicate, consisting of different kinds of operators (distributive quantifiers, focalized expressions) or a verbal modifier as indicated by the scheme (3) (É. Kiss 1994; 1998; Szabolcsi 1997):

(3) Topic* - Distributive Quantifier* - Focus/Verbal modifier - Verb - Postverbal Material

The boundary between the topic and the logical predicate can usually be identified by prosodic means ${ }^{2}$ as well: according to É. Kiss $(2002,11)$,

1 The main purpose of this paper is to investigate the discourse function of nominal expressions (called NPs for the sake of simplicity); therefore, other categories (such as adverbials) that can play the role of topic will be neglected here.

${ }^{2}$ On the difficulties of applying the prosodic criterion in the case of a syntactically complex topic, see Kálmán (2001). 
"the first obligatory stress, which also represents the heaviest grammatical stress in the sentence, falls on the first major constituent of the predicate."

As for the discourse function of topic, it is defined as denoting the individual about which something is asserted by the logical predicate (É. Kiss 1994; Kálmán 2001). Since the referent of a topic expression must always be identifiable in order to be able to assert something about it (É. Kiss 2000; Maleczki 2003), the topic expression must be a referring expression, i.e., it must be referential and specific. ${ }^{3}$ The term "specificity" should be taken in the sense of Enç (1991), who considers an NP specific if it refers to an individual anchored in the discourse context; that is, the referent of a specific NP is either already introduced in the discourse or is a member of a contextually determined set. These requirements are reflected by the following definition proposed by É. Kiss:

"The topic foregrounds an individual (a person, an object, or a group of them) from among those present in the universe of discourse as the subject of the subsequent predication."

(É. Kiss 2002, 9)

It follows from these properties that among non-generic expressions only definite NPs (proper names such as Péter, Mari or definite descriptions such as a fiú 'the boy', ezek a lányok 'these girls' etc.) and specific indefinite NPs (indefinite pronouns such as valaki 'somebody', common nouns introduced by numerals such as két gyerek 'two (of the) children' or indefinite determiners such as valamelyik gyerek 'one of the children') can occupy the position of the topic of the sentence. ${ }^{4}$

On the basis of these claims, we can characterize sentences (4)-(6) as having a topic-comment (logical subject-logical predicate) articulation:

(4) Mari 'szereti az almás pitét.

Mary likes the apple pie

'Mary likes apple pie.'

${ }^{3}$ As É. Kiss (2002) points out, generic NPs also meet the requirement of identifiability - in this sense they should be taken as referential expressions; that is, they can play the role of the sentence topic.

${ }^{4}$ There is a certain disagreement concerning the information structure status of NPs introduced by a legtöbb 'most': Szabolcsi (1997) considers them as topic expressions, whereas É. Kiss (1998) and Kálmán (2001) argue for their quantificational/predicative nature. 
(5) Két gyerek már 'megette az ebédjét.

two child already eat the lunch-his

'Two children have already finished their lunch.'

(6) Sok barátom 'jobban szereti a klasszikus zenét, mint a rockot. many friend-my better like the classical music than the rock

'Many of my friends prefer classical music to rock.'

In (4), the position of the topic is filled by the proper name Mari, denoting an individual present in the universe of discourse of the participants in the sense that this individual is supposed to be known by speaker and listener alike; the predicate asserts that the individual called Mari likes apple pie.

Sentence (5) contains a specific indefinite NP (két gyerek 'two children') playing the role of the topic. This NP denotes a subgroup of a contextually determined set of children and the predicate asserts about this subgroup that its members have already finished their lunch.

As for (6), the position of the topic is occupied here by the indefinite sok barátom 'many of my friends' denoting a relatively large subclass of a group of people fully identifiable for the speaker. The predicate of the sentence asserts about this subclass that its members prefer classical music to rock.

The topic-comment articulation of (4)-(6) can be supported by prosodic arguments: although they can be pronounced in several ways, in each of them the constituent marked by "“" bears the first obligatory accent of the string.

Sentences (7)-(8) below illustrate the sentence type that is topicless and consists of a complex predicate covering the whole sentence:

(7) 'Sok barátom eljött a partira.

many friend-my came the party-to

'Many of my friends came to the party.'

(8) 'Minden barátom/ még 'Péter is szereti a klasszikus zenét.

all friend-my/ yet Peter also likes the classical music

'All of my friends like classical music./

Even Peter likes classical music.'

Both sentences contain a distributive quantifier in the sentence-initial position bearing the first obligatory accent of the sentence. The position 
of the topic remains unfilled in these sentences; consequently, they lack topic-comment articulation.

There is a special kind of topic expression, called contrastive topic, which occurs in the same syntactic position and is claimed to have the same information structure status as the ordinary topic; at the same time, contrastive topics have certain prosodic and semantic features distinguishing them from other kinds of topics. ${ }^{5}$

First, contrastive topics are characterized by a prosodic prominence and a fall-rise intonation contour (noted by " $\vee$ " below) and by the obligatory presence of another prosodically prominent element of the sentence called the associate of the contrastive topic:

(9) `Mari az 'almás pitét szereti.

Mary the apple pie likes

'As for Mary, she likes apple pie.'

In (9), Mari is pronounced with a (fall)-rise intonation contour, and the constituent az almás pitét 'apple pie' has focus stress.

Second, a sentence containing a contrastive topic is claimed to bear a special implicature, related to the fact that the contrastive topic constituent refers to an individual being a member of a set consisting of the alternatives of this individual. Such a sentence implies that there are other individuals in the set of alternatives for which the main predicate of the sentence (possibly) does not hold. In the case of (9), for instance, the individual denoted by Mari is contrasted with other individuals in the discourse domain being possibly fond of dishes other than apple pie.

In Hungarian, it is not only referential expressions that can function as contrastive topic, but other types of expressions (such as certain quantifiers or bare common nouns) that otherwise would never occur in the position of the sentence topic. As É. Kiss (2000) and É. Kiss-Gyuris (2003) point out, this can be explained by the fact that an expression functioning as a contrastive topic can denote a higher order individual, for instance (the name of) a property in the case of a bare common noun or a property of plural individuals, in the case of a quantifier. This also explains the apparent scope inversion attested in sentences containing a quantifier playing the role of the contrastive topic:

\footnotetext{
${ }^{5}$ For an overview of the diverse conceptions of the topical and focal character of contrastive topics, see Molnár (1998). For a detailed analysis of contrastive topic in Hungarian, see Gyuris (2002).
} 
(10) `Marslakót még `soha nem láttam.

Martian yet never no saw-1sg

'I have never seen a Martian.'

(11) `Legalább két filmet 'mindegyik diák megnézett.

at least two film-acc each student watched

'Each student saw at least two films.'

Sentence (10) asserts about the property of being a Martian that the speaker has never seen an individual with this property. On the other hand, the sentence implies that there are possibly other properties comparable to that of being a Martian (any kind of strange property), instances of which the speaker has already seen. As for (11), the sentence asserts about the property of being a plurality consisting of two films that each student saw an instance of this property.

\section{Some problems with assumptions about the notion of topic}

\subsection{Specificity}

In order to be able to appear in the position of topic, an NP in Hungarian must meet the condition of specificity. However, as Maleczki $(2001 ; 2003)$ points out, this notion cannot be considered a dichotomy; rather, there are expressions that are more or less identifiable in a given context.

An expression can be fully identified if its referent is part of the situation or if its referent is known by both speaker and listener - this is the case of proper names, deictic pronouns or definite descriptions related to speaker or listener (my mother, your friends, etc.). Definite descriptions can also be identified by means of discourse context (a definite description normally refers to an individual already mentioned in the preceding context). Finally, an indefinite is (more or less) specific if its referent is somehow linked to the situation or to the preceding context. Consider the following examples:

(12) Egy gyerek virágot szed a kertedben.

a child flower-acc picks the garden-your-in

'A child is picking flowers in your garden.'

(Maleczki 2001, 161) 
(13) Egy gyerek már felébredt.

a child already pfx-woke

'A child has already woken up.'

(idem.)

(14) Egy gyerek kiszaladt az úttestre.

a child pfx-ran the roadway-onto

'A child has run out onto the roadway.'

(ibid., 162)

According to Maleczki (2001), in (12) the most natural interpretation of egy gyerek 'a child' is a totally unknown child, in (13) the subject NP refers to a member of a previously given set of children, whereas in (14) the same NP is ambiguous with respect to specificity: its referent can be unidentified or specific. Notice, however, that in the case of (14), discourse-linkedness can be taken in several ways: the subject NP can denote a member of a previously mentioned set of children or just a member of the set of passers-by. Even in this case we can talk about a discourse-linked referent, since a discourse that describes events that take place in the street naturally presupposes the existence of certain elements of the events such as vehicles and passers-by.

Similarly, the sentence-initial indefinite NPs in (15) are difficult to analyse in terms of specificity:

(15) Egy újságban/ az egyik újságban azt olvastam,

a newspaper-in the one newspaper-in that-acc read-1sg

hogy ötösikrek születtek Új-Zélandon.

that quintuplets were born New Zealand-on

'I read in a newspaper/one of the newspapers that quintuplets were born in New Zealand.'

The difference between NPs of the type egy újság 'a newspaper' and az egyik újság 'one of the newspapers' is that the former is ambiguous between a specific and a non-specific reading, whereas the latter has an unambiguously specific (i.e., partitive) reading. However, as (15) illustrates, both can be used to refer to a particular newspaper without having previously mentioned a set of newspapers. One can argue that we do not need any previously introduced superset here since the sentence-initial NP denotes a member of a maximal set, i.e., the set of all (relevant) newspapers - this maximal set is comparable to the referent of a generic $\mathrm{NP}$ and as such, is identifiable independently of any context. The problem is, however, that along the lines of such reasoning any preverbal (non- 
bare) indefinite NP should be considered specific, including the subject of (12) above.

Lambrecht (1994) makes a distinction between a specific and a nonspecific NP by claiming that the referent of the former is identifiable for the speaker but not identifiable for the listener, while the referent of the latter is not identifiable for the speaker either. However, the discourselinkedness of a non-specific NP does not necessarily guarantee its identifiability. Consider (16)-(17):

(16) Az egyik gyerek hiányzik.

the one child misses

'One of the children is missing.'

(17) Valaki/ Valamelyik diák elvesztette a laptopját.

somebody some student lost the laptop-his-acc

'Somebody/one of the students has lost his laptop.'

One can utter (16) without being able to identify the referent of the NP az egyik gyerek 'one of the children' - it is enough to count the children in question; that is, one can identify a set without being able to identify its members taken individually. Similarly, we don't have to identify the student in question in order to be able to utter (17) - the sentence can be uttered in a situation where the speaker sees an abandoned laptop in an empty lecture hall. On the other hand, one can indifferently use valaki 'somebody' instead of valamelyik diák 'one of the students' without perceiving any difference in their information structure status or syntactic behavior.

É. Kiss $(2002,11)$ is also aware of the fact that NPs denoting nonidentified (i.e., non-specific) individuals can appear in topic position. She exemplifies this with $(18 \mathrm{a}-\mathrm{b})$ below:

(18) (a) Valaki kopog.

somebody knocks

'Somebody is knocking.'

(b) Valami leesett a tetőröl.

something pfx-fell the roof-from

'Something has fallen from the roof.'

É. Kiss proposes to consider here the NPs valaki 'somebody' and valami 'something' as specific in the sense that $(18 \mathrm{a}-\mathrm{b})$ are normally used "in 
situations in which the existence of an unidentified person or object has been inferred - e.g., when knocking has been heard at the door, or an object has been seen flying past the window, respectively" (É. Kiss $2002,11)$. However, this reasoning is weakened by the existence of examples like (19):

(19) Valaki tegnap bekopogott az ajtómon.

somebody yesterday pfx-knocked the door-my-on

'Somebody knocked at my door yesterday.'

In fact, at the moment of the utterance of (19) there is obviously nothing that allows one to infer the existence of the referent of valaki-sentence (19) asserts the existence of an individual with the property of having knocked at the speaker's door the day before. ${ }^{6}$

All these arguments tend to the conclusion that NPs that denote completely unidentified referents can also appear in topic position. On the basis of the assumption that an indefinite that denotes a brand-new referent cannot function as the topic of the sentence, Maleczki (2003) claims that such an NP - even if it appears in the preverbal field - does not fill the position of the sentence topic. However, one cannot postulate an intermediate syntactic position between the topic and distributive quantifiers, since non-specific indefinites can even precede specific NPs in the preverbal field:

(20) (a) Marinak valaki szerelmesleveleket ír.

Mary-to somebody love letters-acc writes

(b) ?Valaki Marinak szerelmesleveleket ír.

somebody Mary-to love letters-acc writes

'Somebody writes love letters to Mary.'

In fact, the version in which a specific (for example a definite) NP precedes a non-specific one (as in (20a)) is slightly more acceptable than the opposite word order (exemplified in (20b)), but this can be explained by a general requirement according to which an NP higher on the specificity scale tends to precede an NP lower on that scale:

${ }^{6}$ On the other hand, (19) illustrates the application of a topic-test frequently used in Hungarian syntax. Unstressed sentence adverbials such as tegnap 'yesterday' are claimed to precede or follow the topic but never be part of the predicate. According to this test, the NP valaki 'somebody' fills the topic position here. 
(21) (a) Marinak valamelyik diák szerelmesleveleket ír. Mary-to some student love letters-acc writes

(b) ?Valamelyik diák Marinak szerelmesleveleket ír. some student Mary-to love letters-acc writes 'One of the students writes love letters to Mary.'

Although (21a-b) contain only specific NPs in topic positions, (21a) is more acceptable since a definite NP is more specific than a specific indefinite NP. ${ }^{7}$

\subsection{Ambiguity with respect to the thetic-categorical distinction}

Following a terminology originally used by Marty (1918) and Brentano (1973), a sentence with a topic-comment articulation is often called a categorical sentence (i.e., expressing a categorical judgment), whereas a topicless sentence is called a thetic sentence (i.e., expressing a thetic judgment). The difference between the two sentence types can be captured by means of preceding questions for which the sentence under consideration constitutes an adequate answer. Since a categorical sentence asserts something about a topic referent, this sentence type normally answers a $w h$-question about this referent. On the other hand, thetic sentences are claimed to assert something about a particular event or situation; hence they are appropriate answers to questions of the type "What happened?", "What's the news?", "What's the problem?".

The question-answer pairs of the two types described above are exemplified in (22) and (23):

(22) Q: Hol van Mari?

'Where is Mary?'

A: Mari a kertben dolgozik.

Mary the garden-in works

'Mary is working in the garden.'

7 The same prominence requirement can be formulated in terms of subject prominence as well as animate prominence: in fact, a subject tends to precede a nonsubject and an NP denoting an animate referent tends to precede an NP denoting an inanimate in topic position. These requirements are sometimes in conflict with each other, resulting in more or less acceptable sentences. 
(23) Q: Mi történt?

'What happened?'

A: Megérkeztek a vendégek. arrived-pfx the guests

'The guests have arrived.'

In (22), sentence A expresses a categorical judgment in the sense that it asserts about Mary that she is working in the garden. On the other hand, sentence A in (23) corresponds to a thetic judgment since it asserts about a particular situation that the arrival of the guests took place in that situation.

In Hungarian, a sentence in which the topic position is filled by a constituent is claimed to express a categorical judgment whereas a sentence with a verb in sentence-initial position is considered to express a thetic judgment. However, this is only partially true. In fact, a sentence with a verb in the leftmost position can never answer a question about the referent of a constituent in its postverbal domain; that is, questionanswer pairs of the type (24) are never acceptable:

(24) Q: Mi történt Gézával?

'What's happened to Géza?'

A: ${ }^{\#}$ Meghalt Géza. ${ }^{8}$

died-pfx Géza

'Géza is dead.'

However, a sentence in which the topic position is filled can often (though not always) function as a correct answer to the question "What's happened?". Consider for instance (25):

(25) Mari beteg/ megbetegedett.

Mary ill became-ill-pfx

'Mary is ill/has got ill.'

Sentence (25) can constitute a correct answer to both types of question, i.e., to "What's happened?" as well as to "What's happened to Mary?". Moreover, in this particular case, the verb-initial version would be odd even if it replies to the question "What's happened?":

8 The symbol "\#" marks that the sentence under consideration is acceptable but does not fit the preceding question 
(26) Q: Mi történt?

'What happened?'

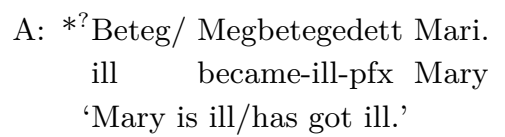

Since (25) can appear in two types of contexts exemplified by the two types of questions, we conclude that the sentence is ambiguous with respect to the thetic-categorical distinction. If we identify theticity with the property of lacking a topic constituent, we must claim that in its thetic reading the constituent that fills the topic position in (25) does not play the role of the topic of the sentence.

Even though there is no structural difference related to the two readings of sentences like (25), they can be uttered following two types of intonation pattern: in the first, the constituent in topic position is unaccented, while in the second accent is equally distributed to each major constituent of the sentence, including the one occupying the topic position. As Varga (1987) points out, the latter corresponds to a reading in which the constituent in topic position introduces a brand-new referent. This brand-new referent can in fact be denoted by a specific (or even by a definite) NP if this referent has not been mentioned in the preceding discourse.

\subsection{Two types of thetic sentences}

We have seen in sections $\mathbf{2 . 1}$ and $\mathbf{2 . 2}$ that it is not only verb-initial sentences that can express a thetic judgment, but also sentences in which the topic position is filled with a non-specific or even a specific (definite) expression.

Moreover, as Gécseg and Kiefer (forthcoming) point out, a sentence that expresses a thetic judgment, i.e., an assertion about a particular event, can be realized by using different word orders. Consider sentences (27)-(28):

(27) (a) Bodri megharapta Marit.

Bodri bit Mary-acc

'Bodri has bitten Mary.' 
(b) Marit megharapta Bodri.

Mary-acc bit Bodri

'Mary has been bitten by Bodri.'

Sentence (27a) can be uttered by means of two neutral intonation patterns corresponding to two types of contexts illustrated by the questions (28ab):

(28) (a) Mit csinált Bodri?

'What's Bodri done?'

(b) Mi történt?

'What's happened?'

In the context created by (28a), the constituent Bodri is unaccented and the sentence expresses a categorical judgment about the referent of Bodri, while in the context created by (28b) sentence accent is equally distributed to Bodri, megharapta and Marit and the sentence expresses a thetic judgment about a particular event of Mary's being bitten by Bodri. Similarly, with the two neutral intonation patterns indicated above, (27b) can serve as an answer to a question about Mary as well as to a question about a particular event.

It follows from these facts that $(27 \mathrm{a}-\mathrm{b})$ are synonymous in their thetic reading in the sense that they can appear in the very same context (created by the question "What's happened?"). However, in spite of the truth-conditional and contextual equivalence that characterizes the variants (a) and (b), there is an important difference between them. Independently of the possible contexts in which they can be used, the difference between their word order suggests that in (27a) something is asserted about Bodri, and in (27b) something is asserted about Mary. This can be accounted for by scheme (1) only if we consider Bodri and Mari to be the topic of sentences (27a) and (27b), respectively. However, this cannot be the case if we interpret them as thetic sentences.

Consider now $(29 \mathrm{a}-\mathrm{b})$ :

(29) (a) Egy kutya megharapott egy járókelőt.

a dog bit a passer-by-acc

'A dog has bitten a passer-by.'

(b) Egy járókelőt megharapott egy kutya.

a passer-by-acc bit a dog

'A passer-by has been bitten by a dog.' 
Since the constituents egy kutya 'a dog' and egy járókelöt 'a passer-by-acc' denote completely unknown referents here, only the thetic (i.e., topicless) reading is available for the two word order variants. ${ }^{9}$ Yet, as we saw in the case of $(27 \mathrm{a}-\mathrm{b})$, in this reading the two sentences must be taken to be contextually equivalent. ${ }^{10}$ However, if we admit the assumption that any change in word order must be motivated on some ground, we must assume that there is a difference in their interpretation. In fact, independently of their contextual equivalence, (29a) asserts something not only about a particular event, but also about a(n unidentified) dog and similarly, (29b) asserts something about the same event but from the point of view of another participant of this event, a(n unidentified) passer-by.

\subsection{Ordinary topic vs. contrastive topic}

As we saw in section $\mathbf{1}$, the distinction between ordinary and contrastive topic is based primarily on prosodic and semantic criteria. In many cases, however, it is very difficult to decide whether a constituent in topic position should be taken to be an ordinary or contrastive topic.

Compare sentences $(30 \mathrm{a}-\mathrm{b})$ :

(30) (a) Mari 'Pétert csókolta meg.

(b) `Mari `Pétert csókolta meg.

Mary Peter-acc kissed pfx

'As for Mary, it is Peter that she kissed.'

In both sentences, the constituent Mari is in topic position and the sentences contain a focused expression (Pétert). In (30a), the topic is unaccented while in $(30 \mathrm{~b})$ the same constituent is pronounced with a prominent stress and a rising intonation contour. Moreover, (30a-b) appear in two context types, exemplified by (31a) and (31b), respectively:

(31) (a) Kit csókolt meg Mari?

'Whom did Mary kiss?'

${ }^{9}$ This is also reflected by their intonation pattern: they can only be uttered with equally distributed accents on the common nouns and the (prefixed) verb in them.

10 This confirms the assumption made by Kuroda (1972) who claims that passivization in languages like English cannot be taken to play the specific role of making the object the topic (in his terminology, the logical subject) of the sentence, since such an object can denote an indefinite (i.e., unidentified) referent as well. 
(b) Kit csókoltak meg a lányok?

'Whom did the girls kiss?'

The difference between the two types of question originates in the fact that the sentence (30b) that contains a contrastive topic implies that there can be somebody else in the discourse domain who possibly kissed somebody other than Peter. Notice that this possibility is not excluded by (30a), but the intonation contour of (30b) makes this possibility more explicit, i.e., (30b) expresses that such an eventuality is "under consideration".

If we replace the definite expression in topic position with an indefinite $\mathrm{NP}^{11}$ with a specific reading in (30), the difference between the two types of topic tends to disappear:

(32) (a) Az egyik lány 'Pétert csókolta meg.

(b) ${ }^{\vee}$ Az egyik lány `Pétert csókolta meg.

the one girl Peter-acc kissed pfx

'One of the girls kissed 'Peter.'

(33) (a) Sok lány 'Pétert csókolta meg.

(b) `Sok lány `Pétert csókolta meg.

many girl Peter-acc kissed pfx

'Many of the girls kissed 'Peter'

For sentences $(32 \mathrm{~b})$ and $(33 \mathrm{~b})$, if we consider only the reading in which the sentence-initial NP has a scope over the focused one (the other possibility will be accounted for later), (32a-b) and $(33 \mathrm{a}-\mathrm{b})$ can be used to answer the very same question, i.e., (34):

(34) Kit csókoltak meg a lányok?

'Whom did the girls kiss?'

In fact, the difference between the two intonation contours which characterize the (a) vs. (b) sentences is very hard to perceive and the two types of sentences can often replace each other in the same context. This

11 Although the topic NP in (32) is introduced by the definite determiner $a(z)$ 'the', the NP as a whole must be considered as an indefinite expression since it denotes a member of the set (of sets) denoted by its common noun part in the same way as the indefinite két lány 'two girls, two of the girls' denotes a member of the set (of sets) denoted by the common noun lány 'girl'. 
is explained by the fact that specific indefinites have per definitionem a partitive reading; that is, they denote a member (or a subset) of a contextually determined set. Their contrast implicature is equivalent in this case to an aspect of the Gricean maxim of quantity: the use of a partitive expression should imply that there are other relevant members of the contextually determined set for which the predicate of the sentence does not hold. Sentences (33a-b) are particularly interesting in this respect: NPs of the type sok $N$ 'many Ns' can appear in topic position only if the sentence contains a constituent with prominent stress, for example a focused constituent. ${ }^{12}$ Compare (35) and (36):

(35) (a) Mari `megérkezett Szegedre.

(b) *`Mari megérkezett Szegedre.

Mary arrived-pfx Szeged-to

'Mary has arrived in Szeged.'

(36) (a) *Sok lány `megérkezett Szegedre.

(b) 'Sok lány megérkezett Szegedre. many girl arrived-pfx Szeged-to 'Many girls have arrived in Szeged.'

Since in sentences (35)-(36) the verb megérkezett 'has arrived' cannot bear contrastive stress, they are never uttered with the same intonation pattern. To put it differently, the NP sok lány 'many girls' cannot have an (ordinary or contrastive) topic accent but must bear the first obligatory stress of the sentence, it must consequently be taken to belong to the logical predicate (i.e., comment) of the sentence.

On the other hand, a sentence containing a verb that usually has prominent stress in Hungarian such as szeret 'likes' allows both types of accentuation for sok $N$ 'many Ns':

(37) (a) Sok gyerek 'szereti az almás sütit.

(b) 'Sok gyerek szereti az almás sütit.

many child likes the apple pie

'Many children like apple pie.'

12 Gécseg (2001) characterizes NPs introduced by the determiner a legtöbb 'most' in a similar way: she considers NPs of this type to be inherently contrastive topics on the basis of the claim that they always appear in a sentence with a prominent associate. 
In (37a) sok gyerek 'many children' fills the topic position of the sentence, whereas in (37b) it belongs to the logical predicate. However, (37a) appears only in very special, polemic contexts like the one exemplified by dialogue (38):

(38) A: Sok gyerek 'gyülöli az almás sütit. many child hates the apple pie 'Many children hate apple pie.'

B: Tévedsz, sok gyerek 'szereti az almás sütit. 'You're wrong, many children like apple pie.'

In a context of this type, the constituent that appears in topic position is typically characterized by the same rising intonation contour as contrastive topics, even if the sentence does not have the contrast implicature previously related to contrastive topics.

A type of topic with an unambiguously contrastive topic intonation and a special interpretation is the quantificational NP with a narrow scope over its associate. ${ }^{13}$ According to É. Kiss and Gyuris (2003), the main function of their rising intonation contour is to individuate a property denoted by a quantificational NP.

As (39) illustrates, such a quantificational NP can function as an answer to a question about quantities:

(39) Q: Kit csókolt meg legalább kettő lány?

who-acc kissed pfx at least two girl

'Who was kissed by at least two girls?'

A: 'Legalább kettő lány `Pétert csókolta meg.

at least two girl Peter-acc kissd pfx

'It is Peter who was kissed by at least two girls.'

The examples above show that the denomination 'contrastive topic' covers an extremely heterogeneous class of data in Hungarian: there are many cases that cannot be differentiated from the ordinary topic, and the cluster of prosodic and semantic properties usually related to con-

13 Another type of expression that can never appear in topic position without the characteristic intonation contour of the contrastive topic is the bare common noun, functioning normally as a verbal modifier in Hungarian. According to É. Kiss (2000), the contrastive intonation and interpretation of such NPs is a way of individuating the property they denote.

Acta Linguistica Hungarica 53, 2006 
trastive topics does not hold for all cases. In section 4, we will examine how to characterize this heterogeneous category with respect to topicality.

\section{Categorical and thetic judgments: the origins of the distinction}

I assume that most of the problems discussed in section $\mathbf{2}$ can be traced back to a confusion about the notions of topic and logical subject on the one hand, and the nature of the categorical-thetic distinction, on the other. In fact, the current approaches to the topic in Hungarian theoretical linguistics take this notion as synonymous with that logical subject.

It is a well-known fact that the notion of topic can be defined in several ways. Most of the relevant definitions are based on the notion of "aboutness" and/or that of "givenness". The topic definition currently used in order to explain sentence structure in Hungarian is essentially based on "aboutness"; that is, a constituent occupying a certain syntactic position will be interpreted as the topic of the sentence independently of the context in which the sentence is uttered. On the other hand, the distinction between thetic and categorical sentences, as is demonstrated by the question-tests used to determine whether a sentence is thetic or categorical, is strongly related to the contextual properties of sentences.

The interpretation of the terms "categorical" and "thetic" has altered considerably since their introduction by Brentano and Marty. According to the theory of (Brentano 1973 [1874]) and Marty (1918), a categorical judgment is a double cognitive act, which consists of the recognition of a (logical) subject and the affirmation or denial of what is expressed by the predicate about the subject:

(40) Diese Blume ist blau.

'This flower is blue.'

(41) Mein Bruder ist abgereist.

'My brother has left.'

A thetic judgment is a logically simple judgment consisting of the act of recognizing or rejecting the content of a judgment:

(42) Es regnet.

'It's raining.' 
(43) Gott ist.

'God exists.'

As (40)-(43) show - and this is also made clear by the authors - there is no direct relationship between the grammatical structure of a sentence and the type of judgment it expresses. Notice furthermore that Brentano and Marty have analysed decontextualized sentences only. They have claimed that the type of judgment expressed by a sentence does not depend on the context but on the logical structure of the sentence; ${ }^{14}$ consequently, the question of a possible ambiguity between the thetic and the categorical reading (in the case of (41), for instance) does not even arise in their theory. Moreover, as Kuroda (1972) notes, Brentano and Marty do not consider sentences like (44) to express a thetic judgment:

(44) Ein Hund rennt.

'A dog runs.'

The great revival of the notions of categorical and thetic judgment and their application to the analysis of particular languages is in fact due to Kuroda (1972) as well as to Kuno (1972). Kuroda (1972) re-evaluates Brentano and Marty's logical theory on the basis of linguistic considerations and he points out that certain morphological characteristics of Japanese can be explained by means of the distinction between the two types of judgment. Sentence (45a) - in which the particle $g a$ is attached to the noun inu 'dog' - corresponds to a thetic judgment, and sentence (45b) - in which the particle wa follows the noun inu-expresses a categorical one:

(45) (a) Inu ga hasitte iru.

'A/the dog is running.'

(b) Inu wa hasitte iru.

'The dog is running.'

Although Kuroda does not consider the morpheme wa as a topic marker (he keeps the original term 'logical subject' in order to avoid the confusion created by the various approaches of the notion of topic), he characterizes

${ }^{14}$ Notice also that, as Kuroda (1972) points out, the Japanese version of the sentence Gott ist 'God exists' includes the topic marker wa (kami wa sonzai suru); hence it would be considered a categorical sentence in Japanese. The same is true for the Hungarian version, Isten létezik. 
the difference between (45a) and (b) in terms of contextual properties. He points out that sentence (45a) is used in a context where no dog was mentioned before, while sentence (45b) is uttered if the identity of the dog is already established in the preceding context. Furthermore, in the case of a thetic reading, both the definite and the indefinite interpretations are available for inu; for the categorical reading, however, only the definite interpretation is possible. This also shows that there is an important restriction in Japanese with respect to the referential properties of a $w a-$ marked expression: it must be a definite NP or, as Kuno (1972) points out, if an NP other that a definite one (a quantificational NP, for instance) is $w a$-marked, it must be uttered with a special intonation and must be interpreted as implying a contrast.

In Lambrecht (1994), the thetic-categorical distinction is clearly analysed on pragmatic rather than logical grounds. In his approach, the topic of the sentence is always identified with respect to a particular discourse, that is, contextual determinacy plays a crucial role in the notion of topic he adopts. As for the possible interpretations of the theticcategorical distinction, he argues in favor of an information structure approach to the thetic-categorical contrast which is based on pragmatic and not logical categories. He considers a sentence with topic-comment articulation to represent a categorical judgment and a sentence without such an articulation (i.e., a topicless sentence) to represent a thetic judgment. On the other hand, Lambrecht points out that the same syntactic structure, expressing the same logical proposition, can have different information structures in different discourse contexts. For example, sentence (46a) is compatible with both of the questions (46b) and (c):

(46) (a) The children went to school.

(Lambrecht 1994, 121)

(b) What did the children do next?

(c) What happened?

Nothing in the syntactic or semantic structure of (46a) determines its information structure. The categorical or thetic character of the sentence is clearly a matter of pragmatics and must be dissociated from its syntactic and logical properties.

The approaches presented in this section show that the thetic-categorical contrast, which was originally established on logical grounds, has in recent decades become a distinction that concerns the pragmatic rather than the logical structure of the sentence. The problem with the notion of topic adopted in Hungarian theoretical linguistics is that it is defined 
by means of the notion of logical subject elaborated in the original (logical) theory of Brentano and Marty and not on the basis of the current (pragmatic) interpretation of the thetic-categorical distinction.

\section{The proposal}

The problems discussed in section $\mathbf{2}$ can be solved if we make a clear distinction between the notions of topic and logical subject on the basis of the assumption that these notions belong to two distinct levels of sentence structure. I will assume, following Kiefer (1977) and Gécseg-Kiefer (forthcoming), that a sentence can be analysed on (at least) three levels: on the grammatical, semantico-logical and pragmatic levels. On the first it is grammatical relations that are defined, such as the grammatical subject-grammatical predicate relationship. The second level contains context-free logical relations such as the logical subject-logical predicate relationship and the third level is the site of pragmatic relations that are defined with respect to the particular context in which the sentence is uttered. One of the main relationships defined on this level is that of topic and comment.

\subsection{Logical subject and topic}

According to the basic claim of this paper, word order in Hungarian is determined by semantico-logical rather than pragmatic articulation. In this approach the notion of logical subject is exclusively based on aboutness; that is, a constituent occupying the position of logical subject denotes a referent about which something is asserted by the logical predicate. This referent can even be completely unidentified both by the speaker and the listener of the utterance. On the other hand, the logical subject of the sentence can play the role of the topic as well (although this is not necessarily the case), with respect to a certain discourse, if the identifiability conditions are met. We can define the notions of logical subject and topic as follows:

(47) (a) Logical subject:

The logical subject of a sentence refers to an individual (or group of individuals) about which something is asserted by the logical predicate. 
(b) Topic:

The topic of the sentence refers to an individual (or group of individuals) fully identified by the participants of the discourse and holding a relation of aboutness with the proposition expressed by the sentence with respect to a particular discourse.

As the definitions (47a-b) suggest, there is a certain relationship between the two notions; that is, both of them are expressed in terms of aboutness. If a constituent appearing in topic position denotes a topic referent in the sense of (47b), this constituent is at the same time interpreted as denoting the logical subject of the proposition expressed by the sentence. On the other hand, a constituent in topic position can play the role of the logical subject without denoting a topic in a particular context. Consider for instance (25), repeated here as (48):

(48) Mari beteg/ megbetegedett.

Mary ill became-ill-pfx

'Mary is ill/has got ill.'

Sentence (48) can be taken to assert something about Mary or something about a particular situation, depending on the context. However, as we saw in section 2.2, the syntactic structure (i.e., the word order) of the sentence is the same with the two interpretations. We can solve this puzzle by assuming that in any case there is an assertion about Mary but in some contexts the sentence pragmatically asserts something about a particular situation by means of a proposition which asserts something about Mary. The divergence of the articulations on the two levels (i.e., logical and pragmatic) is reflected by the prosodic properties of the sentence as well: in case of a thetic (i.e., topicless) reading, there is no intonational boundary between the logical subject and the logical predicate.

On the other hand, if the topic position of a sentence is occupied by a non-specific indefinite expression, the latter cannot play the role of the topic since it denotes a completely unidentified referent and, as a consequence, does not meet any condition of topicality. However, the sentence structure reflects that something is being asserted here about a(n unidentified) referent. In this sense we can claim that such a topicless sentence can have a logical subject-logical predicate articulation. This is the case of (29), repeated here as (49): 
(49) (a) Egy kutya megharapott egy járókelőt.

a dog bit a passer-by-acc

'A dog has bitten a passer-by.'

(b) Egy járókelőt megharapott egy kutya. a passer-by-acc bit a dog

'A passer-by has been bitten by a dog.'

As we saw in section $\mathbf{2 . 3}$, the most natural reading of the two sentences above is about a completely unknown dog and a completely unknown passer-by. Consequently, (49a, b) are thetic sentences, in the same way as $(49 \mathrm{c})$ and $(49 \mathrm{~d})$ are thetic sentences:

(49) (c) Megharapott egy kutya egy járókelőt. bit-pfx a $\operatorname{dog}$ a passer-by-acc

(d) Megharapott egy járókelőt egy kutya. bit-pfx a passer-by-acc a dog 'A dog has bitten a passer-by.'

The situation described by $(49 a-d)$ is the same in each case. Nevertheless, we have two basic variants of word order, an NP-initial and a verb-initial order, where the latter corresponds to a complex logical predicate structure and the former to a logical subject-logical predicate structure. In other words, each of the four sentences asserts something about a particular event, this event is presented in (49a) as an assertion about a dog, in (49b) as an assertion about a passer-by and in (49c-d) as an event of biting of a passer-by by a dog.

\subsection{Identifying the topic}

Since the topic-tests commonly used in Hungarian syntax (i.e., the sentence adverbial test and the prosodic criterion $)^{15}$ do not make reference to the particular context in which the sentence is uttered, it is easy to demonstrate that these tests serve to identify the logical subject rather than the topic (except for the cases when these notions overlap).

${ }^{15}$ For a detailed analysis of the sentence adverbial test and the prosodic criterion, see Gécseg-Kiefer (forthcoming).

Acta Linguistica Hungarica 53, 2006 
In the previous sections of this paper another classical topic test, namely the question test ${ }^{16}$ was implicitly applied. This test consists of the identification of an appropriate context in which a particular constituent functions as the topic of the sentence. The principle underlying this method can be formulated as follows:

(50) The topic part of a sentence is a (phonetically realized or non-realized) element of the sentence that is coreferential with the logical subject ${ }^{17}$ of a preceding $w h$ question.

Principle (50) is in fact a very strong condition on topicality, because it requires that the topic referent of the sentence should already be introduced in the discourse. In other words, the topic referent of the sentence is an individual that a possible preceding question asks something about.

It is interesting in this respect to see about what kind of entities one can raise a well-formed question, i.e., what kind of NPs can occur in a wh-question. Consider the questions in (51):

(51) (a) Mit csinál Mari?

'What is Mary doing?'

(b) ${ }^{? ?}$ Mit csinál az egyik gyerek?

'What is one of the children doing?'

(c) ?? Mit csinál három gyerek?

'What are three children doing?'

(d) *Mit csinál mindegyik gyerek?

'What is each child doing?'

(e) *Mit csinál sok gyerek?

'What are many children doing?'

(f) *Mit csinál valaki?

'What is somebody doing?'

${ }^{16}$ The question test can only be applied to non-negated sentences. On the other hand, Gécseg - Kiefer (forthcoming) makes use of the distinction between sentential negation and predicate negation in order to identify the topic constituent of the sentence.

17 This principle is based on the hypothesis that a subclass of wh-questions has a binary structure, i.e., it can be divided into two parts: the first part is constituted by a wh-phrase and a verb and corresponds to what is asked, while the second part is constituted by the postverbal material and corresponds to what is being asked about. In this sense, we can say that such questions typically have a logical predicate-logical subject structure. 
Among the six interrogative sentences above only (51a), a question about the referent of a definite NP (Mari) is totally well-formed. As for (51b) and (c), they are acceptable only in a situation where the speaker notices that one of the children (or three children) is/are doing something that the other children are not doing. But even in these cases one cannot answer them by means of sentences like (52a) and (b):

(52) (a) \# Az egyik gyerek könyvet olvas.

'One of the children is reading a book.'

(b) \# Három gyerek könyvet olvas.

'Three children are reading a book.'

Only answers of the type exemplified in (53), where the topic is a phonetically non-realized personal pronoun, are available for them:

(53) (a) Könyvet olvas.

'He is reading a book.'

(b) Könyvet olvasnak.

'They are reading a book.'

As for questions $(51 \mathrm{~d}-\mathrm{g})$, they are odd in any context. One can attempt to explain the ill-formedness of (51d) by the fact that mindegyik gyerek 'each child' denotes a universal quantifier that belongs to the predicate part of the sentence. However, this explanation does not hold for $(51 \mathrm{e}-\mathrm{f})$ : the postverbal constituent of these questions would obviously occupy the topic position in the corresponding assertive sentences. The problem with them is that sentences $(51 \mathrm{~b}-\mathrm{c})$ and $(51 \mathrm{e})$ are formulated about referents that have not been introduced to the discourse yet. Discourse-linkedness condition is not sufficient here: even if the NPs az egyik gyerek 'one of the children', három gyerek 'three children' and sok gyerek 'many children' can be taken to denote a member (or a subset) of an identified set of children, the referents of such indefinite NPs are not sufficiently identified to be able to serve as a subject for a subsequent predication.

As for (51f), the ill-formedness of this question comes from the fact that something is asked here about a completely unknown referent. This implies that if valaki 'somebody' has non-specific reading, the only question type that can precede a sentence of the form valaki... is the "thetic question" type like "What happened?", for instance.

Consider now question (54) and possible answers to it in (55): 
(54) Mit csinálnak a gyerekek?

'What are the children doing?'

(55) (a) A gyerekek könyvet olvasnak./Könyvet olvasnak. 'The children are reading a book/They are reading a book'

(b) Az egyik gyerek könyvet olvas./(Az) egyikük könyvet olvas. 'One of the children is reading a book./One of them is reading a book.'

(c) Három gyerek könyvet olvas./Hárman könyvet olvasnak. 'Three children are reading a book./Three of them are reading a book.'

(d) Sok gyerek könyvet olvas./Sokan könyvet olvasnak. 'Many children are reading a book./Many of them are reading a book.'

(e) Mindegyik gyerek könyvet olvas./Mindegyikük könyvet olvas. 'Each child is reading a book./Each of them is reading a book.'

Question (54) is a perfect context for each sentence in (55). The members of the question-answer pairs are linked to each other by means of a contextually determined set of children, denoted by the NP a gyerekek 'the children' in (54) and (55a), by the common noun gyerekek 'children' contained in the sentence-initial NPs or by the implicit pronominal NPs in $(55 \mathrm{~b}-\mathrm{e})$. On the basis of the question-test we can conclude that in the sentences $(55 \mathrm{a}-\mathrm{e})$ not only the predicate könyvet olvas(nak) 'is/are reading a book' brings new information about a referent referred to in the preceding question, but the determiner of the sentence-initial NP as well. In the context created by question (54), (55b-d) assert about an identified set of children that there is a particular member (or a subset) of this set for which the main predication of the sentence holds. In other words, these sentences contain a secondary predication of existence related to the indefinite character of the logical subject NP in them. As for (55e), we can maintain the generally accepted claim that this sentence has no logical subject and must be taken as a complex predicate. At the same time, its discourse-linked character shows that something is being asserted here about a set of children; that is, the nominal part of the universally quantified NP mindegyik gyerek 'each child' can be identified as the topic of the sentence. Since the topic does not correspond to a (phrasal) constituent here, we can conclude that this sentence has no topic-comment articulation on the grammatical level. 


\subsection{Applying the question-test to contrastive topic}

We saw in section 4.2 that if we define topicality in terms of givenness and aboutness (in conformity with current assumptions about the topic appearing in categorical sentences), a strict version of question-test should be applied in order to identify the topic in a particular sentence uttered in a particular context. The application of this question-test led to the conclusion that among the definite and indefinite NPs appearing in topic position, only definite NPs can play the role of the topic. On the other hand, the topic expression of the sentence does not always correspond to a (phrasal) constituent in topic position, but can sometimes be identified as the nominal part of an indefinite (or even quantificational) NP, if the common noun contained in such NPs denotes a contextually determined set of individuals.

In this section, we examine whether the question-test defined for the "non-marked case", i.e., ordinary topic, can be applied for contrastive topic as well.

It was pointed out in section $\mathbf{2 . 4}$ that the term 'contrastive topic' refers to a class of linguistic objects characterized by a rather heterogeneous behavior. The classical cases, that of a definite NP functioning as a contrastive topic is relatively uncontroversial: the rising intonation contour of such NPs goes in pair with an implicature of contrast, which is normally absent in ordinary topics. On the other hand, the necessary partitive reading of specific indefinites and certain quantificational expressions makes it difficult to distinguish between "ordinary" and "contrastive" topic function of an expression occupying a topic position in a sentence. Finally, there is a subclass of NPs - namely quantificational NPs - that can never function as ordinary topics; they can nevertheless appear in topic position with the characteristic intonation contour of contrastive topics. At the same time, in topic position they lose their ordinary scope properties by having narrow scope over the operators they precede. As it was pointed out by É. Kiss-Gyuris (2003), the main function of the rising intonation contour of such quantificational NPs is not to imply a contrast, but to individuate the property denoted by the NP.

The first generalization we can make about sentences containing an NP with rising intonation in topic position is that they can never be thetic sentences, since they can never serve as answers to questions of the type "What happened?". 
Let us examine then by means of the question-test whether the "contrastive topic" NP as a whole or only it's nominal part can be taken to be the topic of the sentence.

Consider again question (54), repeated here as (56), and the sentences in (57), serving as possible answers to (56):

(56) Mit csinálnak a gyerekek?

'What are the children doing?'

(57) (a) ${ }^{\vee}$ A gyerekek $\Upsilon^{\vee}$ Ök `könyvet olvasnak (, a `́lnőttek viszont `sétálni mennének).

'The children/They are reading a book (but the adults would rather go for a walk).'

(b) `Mari 'könyvet olvas (, `Feri pedig 'tévét néz).

'Mary is reading a book (and Feri is watching TV).'

(c) ${ }^{`}$ Az egyik gyerek `könyvet olvas. ${ }^{`}(\mathrm{Az})$ egyikük `könyvet olvas. 'One of the children is reading a book./One of them is reading a book.'

(d) `Három gyerek `könyvet olvas./`Hárman `könyvet olvasnak. 'Three children are reading a book./Three of them are reading a book.'

(e) ' Sok gyerek 'könyvet olvas./'Sokan 'könyvet olvasnak. 'Many children are reading a book./Many of them are reading a book.'

(f) ${ }^{\vee}$ A legtöbb gyerek 'könyvet olvas. ${ }^{`}$ A legtöbben `könyvet olvasnak. 'Most children are reading a book./Most of them are reading a book.'

The intonation marks indicate that the intended reading of the sentences in (57) is a contrastive topic reading. However, whereas the contrastive intonation and interpretation in (57a) clearly distinguishes this sentence from the corresponding (55a) in which the topic position is filled by an ordinary topic, it is very hard to make any prosodic or interpretational difference between $(57 \mathrm{c}-\mathrm{e})$ and their ordinary topic counterparts $(55 \mathrm{~b}-$ d). On the other hand, the contextual connection between sentences $(57 \mathrm{c}-\mathrm{e})$ and the preceding question (56) is established - just like in case of $(55 \mathrm{~b}-\mathrm{d})$ - by means of a relation of coreference between the NP $a$ gyerekek 'the children' in (56) and the noun gyerek 'child' or an implicit pronominal-like element in $(57 \mathrm{c}-\mathrm{e})$.

In sentence (57f) the contrastive topic is the quantificational NP $a$ legtöbb gyerek 'most children'. As it was referred to in section 2.4, this NP is sometimes considered as the logical subject (topic) of the sentence, and sometimes is taken to belong to the logical predicate. Furthermore, the fact that NPs of the type a legtöbb $N$ 'most Ns' have partitive reading and 
appear typically in sentences where they are associated to a constituent with prominent accent, it would be quite unnatural to try to make a difference between an ordinary and a contrastive topic function of such an NP. In any case, the "real" topic (in the sense of the definition (47b)) of the sentence (57f) should correspond to the noun gyerek contained in the NP a legtöbb gyerek 'most children', rather than to the NP as a whole.

As for (57b), the non-contrastive counterpart of this sentence would not be an appropriate answer to (56). Moreover, even though no formal link can be observed between the question and the answer, that is, there is no strict coreference between an expression in the question and an (explicit or implicit) element of the answer, the dialogue is coherent. Its coherence is in fact assured by the presupposition (shared both by the speaker and the listener of the utterance) that the referent of the contrastive topic constituent Mari is already identified as a member of a contextually determined set of children. Contrary to specific indefinite expressions like those in $(57 \mathrm{c}-\mathrm{e})$, the referent of the definite NP Mari is identified independently of the main predication of the sentence. Since in this particular context the sentence presupposes, instead of asserting, that the referent of Mari in the answer belongs to the set denoted by $a$ gyerekek 'the children' in the question, this referential autonomy of the definite NP makes possible for it to function as a topic in conformity with the definition of topic given in (47b).

One could be wondering what kind of question can be related to the narrow scope reading of quantificational expressions occurring in (contrastive) topic position. Such a context was exemplified in (39), repeated here as (58):

(58) Q: Kit csókolt meg legalább kettő lány?

who-acc kissed pfx at least two girl

'Who was kissed by at least two girls?'

A: `Legalább kettő lány 'Pétert csókolta meg.

at least two girl Peter-acc kissd pfx

'It is Peter who was kissed by at least two girls.'

In the question part of (58), the NP legalább kettö lány 'at least two girls' is interpreted not as a group consisting of two girls, but as a property of being a group of girls with the cardinality of two. If the first interpretation were correct, (59) would be an appropriate answer to the question in (58): 
(59) \# Pétert csókolták meg.

'It was Peter that they kissed'

On the other hand, the formal and referential identity of the NP legalább kettö lány 'at least two girls' in the question and in the answer indicates that the reference of this NP is contextually established, it can therefore be identified as the topic of the sentence. ${ }^{18}$

\section{Topic vs. logical subject: cross-linguistic evidence}

The main assumption of this paper is that Hungarian is not a topicprominent language, but a logical subject-prominent one. This claim could be strongly supported if we could find languages that display a pragmatic rather than a logical articulation. Such a language would contain contextually unambiguous sentences with respect to information structure and would strongly constrain the referential properties of preverbal NPs.

Reference was made in section 3 to Japanese where a wa-marked expression must be a definite NP and other types of wa-marked NPs must be interpreted as implying a contrast.

Another piece of evidence comes from a spoken version of French, called colloquial French. ${ }^{19}$ It has been observed that colloquial French has a tendency to avoid SVO order systematically in sentences with a non-pronominal subject (Cadiot 1988; Lambrecht 1994; De Cat 2002). Most sentences with a lexical subject - and sometimes even sentences with a pronominal subject - are topicalized structures using (left or right) dislocation of the constituent that plays the role of the topic. A sentence that displays a topic-comment articulation is either a dislocated structure (cf. (60)) or a sentence with a pronominal subject (cf. (61)):

\footnotetext{
${ }^{18}$ In fact, there is no need to apply the question-test in order to demonstrate that quantificational NPs with a narrow scope reading play the role of the topic of the sentence. Such NPs denote quantificational properties and quantificational properties are assumed to have a fixed reference. They can be compared in this respect to generic NPs: their referent can be identified without being introduced to a previous context.

${ }^{19}$ For a detailed analysis of information structure in colloquial French, see De Cat (2002) and Gécseg (forthcoming).
} 
(60) Ma soeur, elle est malade. my sister she is ill 'My sister is ill.'

(61) Elle est malade. 'She is ill.'

Sentences (60) and (61) are categorical sentences in the sense that they serve as answers to questions about the referent of the dislocated NP in (60) and the pronominal subject in (61). (Several constituents can be topicalized in the same sentence; that is, a sentence can contain more than one topic if required by the context.)

As for thetic judgments, they are typically expressed in colloquial French by means of existential constructions with an expletive subject $i l$ (which is often elided in informal speech) or presentative constructions introduced by the morpheme voilà/voici:

(62) (Il) y a ma soeur qui est malade.

it-expl there has my sister who is ill

'My sister is ill.'

(63) Voilà/ (Il) y a Pierre qui arrive.

voilà/ it-expl there has Peter who arrives

'Peter is arriving.'

Sentences (62) and (63) can never be uttered as answers to questions about the referent of ma soeur 'my sister' or that of Pierre. They usually appear at the beginning of a conversation or in the context of questions of the type "What happened?" or "What is happening?".

On the other hand, the nature of topicalized constituents is strictly constrained in colloquial French: topicalization can only affect definite or generic NPs and even specific indefinites cannot be dislocated:

(64) (a) Ce roman, je l'ai lu avec plaisir.

'This novel I liked very much.'

(b) *Un de ces romans, je l'ai lu avec plaisir.

'One of these novels I liked very much.'

At the same time, it is possible to topicalize the nominal part of an indefinite or quantificational expression: 
(65) (a) *Beaucoup de/*Plusieurs/*Deux/*Quelques romans, je les ai lus avec plaisir. '[There are] a lot of/several/two/some novels I liked very much.'

(b) Ces romans, j'en ai lu beaucoup/plusieurs/deux/quelques uns.

'As for these novels, I've read many/several/two/some of them.'

(66) (a) *Tous les romans, je les ai lus avec plaisir.

'As for all of the novels, I liked [them] very much'

(b) Ces romans, je les ai tous lus avec plaisir.

'As for these novels, I liked all of them very much.'

In $(65 \mathrm{~b})$ and (66b), topicalization affects only the nominal part of the quantified expressions, represented as a definite NP in topic position and the determiner remains in situ. These sentences can only be interpreted as asserting about a contextually determined set of novels that a certain quantity of them was appreciated by the speaker.

In certain conditions, not only can a definite NP be topicalized, but also an indefinite expression:

(67) Des chemises, j'en ai des 'propres.

indef.art. shirts I of-them have indef.art. clean-pl.

'As for shirts, I have some that are clean.'

(68) $\mathrm{Du}$ vin, j'en ai du 'bon.

indef.art. wine I of-them have indef.art. good

'As for wine, I have some that is tasty.'

(69) Des fautes, il en fait à la 'douzaine.

indef.art. mistakes he of-them makes to the dozen

'As for mistakes, he makes dozens of them.'

In sentences (67)-(69), the indefinite NP in topic position is interpreted as the name of a property, comparable in this respect to a bare common noun in topic position in Hungarian (exemplified by (10) in section 1). In some contexts a contrastive reading can be associated with such sentences, but this is not necessarily the case. Nevertheless, the behavior of the indefinite topic is similar to that of contrastive topics in Hungarian because in colloquial French the indefinite topic appears in sentences containing a constituent that is uttered with a prominent stress. In the case of a French sentence, this stressed constituent typically occurs at the end of the sentence. On the other hand, the property denoted by the topicalized constituent in sentences like (67)-(69) is always linked to the previous 
discourse, that is, the referent of this constituent meets not only the condition of full identifiability, but also that of contextual boundness.

The examples above show that the preverbal field in colloquial French contains a position reserved for constituents that play the role of the sentence topic. Topicalized sentences only appear in a context where the referent of the topic constituent is already introduced and fully identified. Non-topicalized sentences contain either a pronominal subject or the existential construction (il) y a or the presentative morpheme voilà. In the case of a pronominal subject, this latter always functions as a topic:

(70) Il est malade.

'He is ill.'

Since a personal pronoun denotes an individual already mentioned in the discourse or present in the situation, the subject pronoun $i l$ 'he' is interpreted as the topic of sentence (70), which asserts that the referent of this pronoun is ill.

As for existential and presentative constructions, they can be taken as topicless because they appear typically in contexts where something is being asserted not about an individual, but about an event or a situation.

We can conclude from these data that colloquial French is a topicprominent language in the sense that in this version of French there is a structural position reserved exclusively for a constituent that plays the role of the topic where topicality is defined in terms of full identification, contextual boundness and aboutness.

\section{Summary}

The main purpose of this paper was to examine the properties of the so-called topic constituent in Hungarian sentences. It was pointed out that if we make a strict distinction between the notion of topic, defined on a pragmatic level with respect to possible contexts, and the notion of logical subject, defined on a decontextualized logico-semantic level, Hungarian should be taken as a logical subject-prominent rather than a topic-prominent language. The existence of topic-prominent languages as opposed to logical subject-prominent languages was proved through data from colloquial French. As for the so-called contrastive topic in Hungarian, the results of the analyses show that only a subclass of contrastive topic expressions meets the topicality conditions established in 
this paper on pragmatic grounds, and other types of contrastive topic expressions, namely those that can hardly be differentiated from ordinary topics, display the properties of logical subjects rather than topics.

\section{References}

Brentano, Franz 1973. Psychology from an empirical point of view. Routledge, London. Translated by Antos Rancurello, D. B. Terrell and Linda McAlister from Psychologische vom empirischen Standpunkt (1874/1924).

Cadiot, Pierre 1988. Le thème comme synecdoque. In: Langue Française 78:9-26.

De Cat, Cécile 2002. French dislocation. Doctoral dissertation, University of York.

É. Kiss, Katalin 1994. Sentence structure and word order. In: Katalin É. Kiss - Ferenc Kiefer (eds): The syntactic structure of Hungarian (Syntax and semantics 27), 1-90. Academic Press, New York.

É. Kiss, Katalin 1998. Mondattan [Syntax]. In: Katalin É. Kiss-Ferenc Kiefer-Péter Siptár: Új magyar nyelvtan [A new Hungarian grammar], 15-184. Osiris Kiadó, Budapest.

É. Kiss, Katalin 2000. A [+referáló] és [+ specifikus] jegyek ellenőrzése a kontrasztív topik esetében [The checking of [+ referential] and [+ specific] features in the case of contrastive topic]. In: László Büky - Márta Maleczki (eds): A mai magyar nyelv leírásának újabb módszerei IV [Recent methods in the description of contemporary Hungarian 4], 85-96. JATEPress, Szeged.

É. Kiss, Katalin 2002. The syntax of Hungarian. Oxford University Press, Oxford.

É. Kiss, Katalin - Beáta Gyuris 2003. Apparent scope inversion under the rise fall contour. In: Acta Linguistica Hungarica $50: 371-404$.

Enç, Mürvet 1991. The semantics of specificity. In: Linguistic Inquiry $22: 1-25$.

Gécseg, Zsuzsanna 2001. A kontrasztív topik szintaxisáról és szemantikájáról [On the syntax and semantics of contrastive topic]. In: Magyar Nyelv $97: 283-292 ; 423-$ 431.

Gécseg, Zsuzsanna forthcoming. A magyar és a francia mondat tagolásának alapelvei / Les principes de l'articulation de la phrase assertive dans le hongrois et dans le français parlé. In: Ilona Kassai (ed.): A francia és a magyar mondat információs szerkezete / Structure informationnelle de la phrase française et de la phrase hongroise. Lharmattan \& Tinta Kiadó, Budapest.

Gécseg, Zsuzsanna-Ferenc Kiefer forthcoming. A new look at information structure in Hungarian. In: Linguistics.

Gyuris, Beáta 2002. The semantics of contrastive topic in Hungarian. Doctoral dissertation, ELTE, Budapest.

Kálmán, László 2001. Magyar leíró nyelvtan. Mondattan I (Segédkönyvek a nyelvészet tanulmányozásához VI) [Hungarian descriptive grammar. Syntax 1 (Supplementary textbooks on linguistics 6)]. Tinta Kiadó, Budapest.

Kiefer, Ferenc 1977. Functional sentence perspective and presuppositions. In: Acta Linguistica Hungarica $27: 83-109$. 
Kuno, Sosumo 1972. Functional sentence perspective: A case study from Japanese and English. In: Linguistic Inquiry $3: 269-320$.

Kuroda, Sige-Yuki 1972. The categoric and thetic judgment: Evidence from Japanese syntax. In: Foundations of Language $9: 153-85$.

Lambrecht, Knut 1994. Information structure and sentence form. Cambridge University Press, Cambridge.

Maleczki, Márta 2001. Indefinite arguments in Hungarian. In: István Kenesei (ed.): Argument structure in Hungarian, 157-99. Akadémiai Kiadó, Budapest.

Maleczki, Márta 2003. Information structure, argument structure and typological variation. In: Katarzyna Jaszczolt - Ken Turner (eds): Meaning through language contrast, 223-44. John Benjamins, Amsterdam \& Philadelphia.

Marty, Anton 1918. Gesammelte Schriften. Vol. II., part 1. Abteilung. Max Niemeyer Verlag, Halle.

Molnár, Valéria 1998. Topic in focus: The syntax, phonology, semantics and pragmatics of the so-called "contrastive topic" in Hungarian and German. In: Acta Linguistica Hungarica $45: 89-166$.

Szabolcsi, Anna 1997. Strategies for scope taking. In: Anna Szabolcsi (ed.): Ways of scope taking (SLAP 65), 109-155. Kluwer, Dordrecht.

Varga, László 1987. Hozzászólás egy hangsúly-tanulmányhoz [Remarks on a prosody study]. In: Nyelvtudományi Közlemények 89:53-66. 